\title{
ROMPENDO O SILÊNCIO DA MEMÓRIA: HISTÓRIA ORAL E NARRATIVAS DE VIOLÊNCIAS NO INTERIOR DE MINAS GERAIS
}

\section{BREAKING SILENCE OF MEMORY: ORAL AND NARRATIVE HISTORY OF VIOLENCE IN MINAS GERAIS}

\author{
Érika Oliveira Amorim ${ }^{1}$ \\ Maria Beatriz Nader ${ }^{2}$
}

\begin{abstract}
RESUMO: O presente texto aborda a violência contra a mulher com enfoque em uma cidade de pequeno porte, localizada no interior de Minas Gerais. Analisa a violência doméstica e familiar como um fenômeno social que atinge todas as classes sociais e que encontra no espaço privado, seu maior campo de atuação. Tem como ponto de partida as narrativas de uma mulher que foi agredida pelo companheiro, está sob medida protetiva de urgência e faz acompanhamento psicossocial no Centro de Referência Especializado de Assistência Social (CREAS) na cidade de Carangola, Minas Gerais. Metodologicamente, utiliza a história oral como método-fonte-técnica de pesquisa a fim de possibilitar que as experiências de um cotidiano de violências rompam o silêncio da memória.
\end{abstract}

PALAVRAS-CHAVE: violência; patriarcado; história oral.

\begin{abstract}
This text deals with violence against women with a focus on a small city, located in the interior of Minas Gerais. It analyzes domestic and family violence as a social phenomenon that reaches all social classes and that finds in the private space, its greater field of action. It has as its starting point the narratives of a woman who was attacked by her companion, is under urgent protective measures and does psychosocial monitoring at the Specialized Reference Center for Social Assistance (CREAS) in the city of Carangola, Minas Gerais. Methodologically, it uses oral history as a methodsource-research technique in order to allow the experiences of a daily violence to break the silence of memory.
\end{abstract}

KEY WORDS: violence; Patriarchy; Oral history.

\footnotetext{
${ }^{1}$ Doutoranda em História Social das Relações Políticas da Universidade Federal do Espírito Santo (UFES), bolsista CAPES. Professora no Curso de História da Universidade do Estado de Minas Gerais (UEMG), Unidade Carangola. E-mail: erikaoamorim@hotmail.com

${ }^{2}$ Professora Titular do Programa de Pós-Graduação da Universidade Federal do Espírito Santo (UFES). Coordena o Laboratório de Estudos de Gênero, Poder e Violência (LEG/UFES). E-mail: marxis@terra.com.br
} 


\section{INTRODUÇÃO}

A violência contra a mulher é um fenômeno social que atinge todas as classes sociais e que encontra no espaço doméstico, seu maior campo de atuação. Possui como vetor um ciclo que inicia com ofensas verbais, construindo um ambiente de tensão, evolui para crises mais graves - nas quais a violência se materializa - e desemboca com o arrependimento do agressor, momento no qual tenta se redimir da agressão por meio de presentes e demonstrações de afeto. Esse ciclo de violência é reforçado pelo silêncio, omissão e negligência que pode culminar com o assassinato da mulher. $\mathrm{O}$ título desse trabalho foi pensado com base nesse ciclo da violência contra a mulher o qual também norteia a escrita deste texto.

A tríade silêncio-denúncia-enfrentamento faz parte do processo vivido cotidianamente pelas mulheres que sofrem os diversos tipos de violências. $\mathrm{O}$ silêncio diz respeito não só ao mutismo das mulheres, mas também aos dados estatísticos inconsistentes relacionados às agressões diárias. Se elas não falam, os números não existem e as políticas públicas de combate e enfrentamento são, da mesma maneira, incongruentes. A denúncia se materializa na tomada de decisão em procurar ajuda e é, por muitas vezes, postergada e vencida por inúmeras experiências de agressões. E, por fim, o enfrentamento, etapa na qual as mulheres experimentam o medo do agressor, a rejeição da família, o preconceito da sociedade, a falta de uma rede de apoio e acolhimento e a ambivalência contida no conflito ante a repulsa da agressão e a relação afetiva com o agressor.

Com base nessa tríade, apresenta-se neste texto o relato de uma das mulheres entrevistadas para a pesquisa "Mulher e Patriarcado: um estudo de caso sobre a violência contra a mulher em Carangola - MG (2006-2016)". A fim de garantir o anonimato da entrevistada, optou-se por dar-lhe o nome fictício de Margarida.

\section{Memória e História Oral como metodologia de estudo sobre as mulheres}

A descoberta do aspecto político no âmbito cotidiano levou ao questionamento sobre o funcionamento da família, o significado dos fatos, lutas e 
comportamentos diários. Ao estudar o cotidiano das mulheres permite-se conhecer problemas sociais enfrentados por elas, como a violência que se manifesta de diversas formas e atinge todas as classes sociais.

O uso da história oral para tratar de violências contra a mulher numa pequena cidade do interior de Minas Gerais possibilita evidenciar o papel das emoções nas memórias dessas mulheres. A história oral constitui uma ferramenta metodológica que propicia conhecer as histórias de mulheres comuns e a dinâmica da vida cotidiana. Permite que as experiências de um cotidiano de violências rompam o silêncio da memória.

Segundo Delgado (2010), a história oral é um procedimento metodológico que busca, pela construção de fontes e documentos, registrar, através de narrativas versões e interpretações sobre a História em suas múltiplas dimensões.

No que diz respeito ao uso da metodologia de História Oral nas pesquisas de gênero, a historiadora oral italiana Luisa Passerini afirma que a mesma contribuiu fortemente com os esforços de "genderizar" a história. Para ela, a história de gênero e a história oral caminharam de mãos dadas na ampliação do território da História e na renovação de seus objetos e métodos de estudo (PASSERINI, 2011).

A possibilidade de tornar visível a história de mulheres anônimas comuns é uma das potencialidades da História Oral, pois, como avalia Michelle Perrot (1989) o desenvolvimento recente da história oral é uma revanche das mulheres, tendo em vista que durante muito tempo o relato histórico se esqueceu delas, relegando-as a um "silêncio ensurdecedor" (PERROT, 2005, p. 9).

A memória é a principal fonte dos depoimentos orais que é registrada por meio das narrativas pessoais proporcionando a percepção da dinâmica da vida pessoal em conexão com os processos coletivos. Os relatos de entrevistadas e entrevistados consistem na principal fonte de informação da História Oral. Eles tratam de lembranças individuais, que compõem a identidade das interlocutoras, e os fatos que rememoram fazem parte de memórias proibidas, indizíveis ou vergonhosas (POLLAK, 1989).

Lembrar é dar significado e reconhecer a memória e, em se tratando de uma cidade interiorana e de pequeno porte, na qual os modos de vida conferem estreita relação entre espaços públicos e privados, lembrar-se da violência sofrida, pode ser ainda mais doloroso. Isso porque em locais como esse, dado a maior proximidade entre os indivíduos e ao número reduzido de pessoas, comparado aos grandes centros, há um 
mútuo controle da comunidade na vida privada das pessoas. Nesse tipo de sociabilidade as pessoas estão atentas aos que fazem os outros, o que pode dificultar as mulheres a falarem de si mesmas, e da violência a que estiveram submetidas.

\section{Quem é a Margarida? De quem e de onde se fala}

Essa pesquisa é realizada na cidade mineira de Carangola ${ }^{3}$, localizada na Zona da Mata do estado. Visa conhecer a realidade de mulheres que sofreram violências e denunciaram agressores buscando comprovar que a influência do patriarcado, sobretudo em cidades interioranas de pequeno porte, é determinante do comportamento dos agressores e interfere na decisão das vítimas em oferecer denúncias.

As atrizes sociais deste estudo são mulheres que foram agredidas, estão sob medidas protetivas de urgência e fazem acompanhamento psicossocial no Centro de Referência Especializado de Assistência Social (CREAS), no município supracitado.

A seleção das entrevistadas contou com a mediação da equipe de assistentes sociais da única unidade do Centro de Referência Especializado de Assistência Social $(\mathrm{CREAS})^{4}$ existente na cidade. Devido a inexistência de uma Delegacia Especializada de Atendimento à Mulher (DEAM) os casos de violências contra a mulher são atendidos pela Delegacia de Polícia e encaminhados para o Ministério Público, que por sua vez, direciona as mulheres para atendimentos psicossociais.

Neste texto, apresenta-se o relato da entrevistada Margarida, que possui histórico de abandono e violência desde sua infância. Ela tem 34 anos de idade, reside no meio urbano, trabalha como auxiliar de limpeza e possui ensino fundamental incompleto. Aos três anos de idade, após a morte de seus pais, foi abrigada, junto com suas três irmãs, em uma instituição ${ }^{5}$ que acolhe meninas em situação de abandono. Na adolescência, Margarida e suas irmãs foram adotadas por três famílias diferentes, as quais possuíam parentesco entre si, e que alegavam que as irmãs estariam sempre

\footnotetext{
3 O município de Carangola está situado na Zona da Mata de Minas Gerais, na confluência com os Estados do Rio de Janeiro e Espírito Santo, com uma população de 32.296 habitantes, sendo 16.604 mulheres.

${ }^{4}$ O Centro de Referência Especializado de Assistência Social (CREAS) é uma unidade pública estatal, de abrangência municipal ou regional, referência para a oferta de trabalho social a famílias e indivíduos em situação de risco pessoal e social, por violação de direitos, que demandam intervenções especializadas no âmbito do Sistema Único de Assistência Social (SUAS) (BRASIL, 2011).

${ }^{5}$ Essa instituição é mencionada por Margarida em vários momentos durante a entrevista, e, ora é chamada de "orfanato", ora "instituto". A instituição por onde a entrevistada viveu parte de sua vida é considerada um lugar de memória (Nora, 1993).
} 
juntas, embora residindo em casas separadas. Segundo relata a entrevistada, as meninas passaram a morar com essas famílias a fim de realizar trabalhos domésticos ${ }^{6}$. Aos dezessete anos, após reclamação de maus-tratos, a família que tinha sua tutela entregoua para os tios paternos, numa cidade vizinha. Ela passou a residir com os tios, juntamente com um irmão que já era criado por eles e que, por ser do sexo masculino, não foi aceito no orfanato. A entrevistada conta que viveu um período conturbado nessa época, pois o irmão havia tentado abusar sexualmente dela. Embora se queixasse aos tios, nenhum deles acreditava em Margarida.

A entrevista é permeada por momentos de emoção e, por vezes, confusa, tendo em vista que Margarida rememora fatos em diferentes contextos e épocas. Nessa tessitura de pontos e contrapontos, a entrevistada relata um histórico de violência, relembra pessoas e lugares desde sua infância, quando foi levada para o orfanato, perpassa a adolescência quando viveu sob a tutela de uma família que explorava seu trabalho doméstico e que vai culminar com agressões da filha, já na fase adulta. No relato ela busca traçar sua identidade, não só para ela, mas também para quem a ouve. Quem é a Margarida? - Ela se pergunta enquanto conta sua história.

As memórias de mulheres que sofreram violência formam suas identidades e a imagem que têm delas mesmas e nas representações que possuem. Segundo Pollak (1992) há uma estreita relação entre memória e identidade, porque os acontecimentos vividos pessoalmente constituem a memória individual e determinam marcos, pessoas ou lugares de memória. Para Pollak a construção da identidade é um fenômeno que se produz em referência aos outros, em referência aos critérios de aceitabilidade, de admissibilidade e de credibilidade (POLLAK, 1992, p. 204). É por isso que a entrevistada sempre cita o instituto, pois além de ser um lugar de memória, faz parte de sua identidade enquanto pessoa, ao que irá mencionar sempre: "menina do instituto" ou "essas meninas que são do instituto" de modo a atribuir um estigma negativo pelo fato de ter morado nessa instituição, ocasião em que também relatou ter sofrido violência por parte das funcionárias de lá.

Por ser construída no sentido físico e moral da pessoa, a memória da violência está nas dimensões simbólica e psicológica e em categorias como inconsciente e recalque e, pode estar também, materializada no corpo. Compõe o que Pollak (1989) nomeia de "memórias subterrâneas" e que estão silenciadas por inúmeros fatores: medo,

\footnotetext{
${ }^{6}$ É costume da cidade que famílias passem a ter a guarda de jovens do orfanato para, em troca, utilizarem a mão-de-obra delas em serviços domésticos.
} 
vergonha, dependência financeira, falta de apoio, ou por outros aspectos dolorosos de suas vidas.

Essas experiências tornam a memória um campo de batalha, o que faz dela seletiva. Pollak (1992) nos diz sobre o trabalho da própria memória em si, pois, cada vez que está relativamente constituída, ela efetua um trabalho de manutenção, de continuidade, de organização. Talvez esteja aí a explicação para o relato confuso de Margarida, organizado num vai-e-vem de lembranças, nas quais a violência é uma constante.

\section{Violência e silêncio}

Em se tratando de violências contra as mulheres sabe-se que o espaço doméstico é o local onde as relações de poder e dominação mais se manifestam. Isso porque o espaço privado da casa, numa sociedade pautada em códigos morais patriarcais, naturaliza a opressão das mulheres. A hierarquia entre homens e mulheres, que estabelece a primazia masculina, como afirma Saffioti (2015), neutraliza a exploração-dominação masculina. Dessa maneira, tem-se uma estrutura de poder que confere ao homem violência e agressividade como componentes identitários dos quais lançam mão na iminência da perda do poder que exercem. Assim, pode-se afirmar que a violência e o poder estão imbricados nas relações sociais, e, especialmente, nas relações domésticas.

O grande sustentáculo da violência contra as mulheres está no componente cultural da sociedade, que prescreve um comportamento ideal para homens e mulheres. Pelo fato das agressões ocorrerem em espaços privados e praticados por pessoas conhecidas (Waiselfisz, 2015), a denúncia é vista como imprópria e acaba sendo tolerada pela sociedade.

Nader (2006) disserta que muitas mulheres brasileiras ocultam da própria família as investidas agressivas de seus maridos, pelo medo e pela vergonha que sentem de conviver com um homem que as maltratam. Nesse convívio permeado por agressões, é comum que as mulheres nutram sentimentos ambivalentes e seu auto-culpabilizem.

Para Moreira, Ribeiro e Costa (1992) são os mecanismos de autoculpabilização que aprisionam a mulher no medo e na vergonha. $\mathrm{Na}$ medida em que 
retiram a culpa do agressor, se responsabilizam e procuram em si mesmas uma atitude de falta ou de excesso.

Margarida, na entrevista concedida para a pesquisa relatou o sentimento de auto-culpabilização:

Chegou no outro dia ele saiu pra trabalhar e me trancou dentro de casa e levava a chave e nisso foi onze anos. Não conversava com ninguém, não passava isso pra ninguém porque eu não confiava em ninguém e eu falava "tem que aceitar porque se ele faz isso comigo fazer o que, né?". Ai eu comecei a colocar na minha cabeça que eu estava dando motivo, ele chegava em casa, sempre alguma coisa já na cabeça dele pra poder ter agressão e tudo. Então pra mim eu comecei a colocar na cabeça que eu era errada, que eu traia ele. Ai isso foi virando quatro, cinco, foram anos e anos. (Relato de Margarida, dezembro de 2016).

Nota-se que o comportamento agressivo do companheiro de Margarida foi reiterado por anos e ela, em silêncio, foi mantendo a relação violenta.

O silenciamento das mulheres no que tange as violências às quais estão submetidas abarca alguns fatores, quer sejam emocionais, econômicos e sociais. No aspecto emocional, o silêncio pode se dar em razão da relação afetiva entre o agressor e a vítima. O silenciamento pode também ocorrer devido a dependência financeira da mulher, ou ainda em função de aspectos sociais, temendo o julgamento e/ou a incompreensão da família ou da comunidade a que pertence a vítima.

Pode-se dizer que o processo que se dá desde o início das agressões até a ruptura do relacionamento divide-se em três fases: 1) a fase do silenciamento, quando a mulher vivencia vários tipos de violências (psicológica, sutil ${ }^{7}$, física, sexual, moral, patrimonial) e se cala; 2) A fase da denúncia, quando a violência torna-se insuportável e é denunciada seja pela vítima ou por um vizinho, amigo ou parente, e 3) A fase do enfrentamento, que consiste no momento pós-denúncia, no qual a mulher convive com medidas protetivas e precisa reconstruir sua vida.

Durante essas três fases da vida da mulher que sofre violência, a ambivalência está presente. $\mathrm{Na}$ medida em que a sociedade atribui e inculca nas

\footnotetext{
${ }^{7}$ Conceito desenvolvido pela historiadora e pesquisadora Maria Beatriz Nader (2006). Trata-se de um tipo de violência que é abstrata, impalpável, além de ser somente percebida pela pessoa que a experimenta. Não deixa marcas físicas no corpo, mas magoa e transforma o interior da vítima. A humilhação e o constrangimento são dois exemplos que podem ser destacados como violência sutil.
} 
mulheres a tenacidade e a resiliência para suportar o sofrimento, confere também a capacidade de perdoar e compreender como características inerentes a elas.

$\mathrm{Na}$ entrevista de Margarida nota-se a influência dos fatores emocionais, econômicos e sociais nos momentos de silêncio, denúncia e enfrentamento, como se apresenta a seguir.

\section{O silenciamento por razões emocionais}

Muitas são as violências que envolvem a entrevistada e, em diferentes épocas e contextos: abandono, negligência, exploração de mão-de-obra, tentativa de estupro e incesto, discriminação. No entanto, em seu relato, é notório o peso que ela dá para a violência cometida por seu ex-companheiro. Parece haver, por parte da depoente, a naturalização do processo de violência possivelmente em decorrência de um continuum de experiências que envolveram violências. $\mathrm{O}$ fato de ser uma "menina do orfanato", como ela mesma afirma, corrobora com as sujeições às violências sofridas e, por isso a agressão do companheiro, a quem ela "realmente confiava", representam para ela, as mais dolorosas. Isso porque a violência conjugal é uma forma particular da violência, tendo em vista a relação afetiva entre agressor e vítima. $\mathrm{O}$ laço de afetividade entre o casal estabelece a ambivalência que parece dificultar o enfrentamento da violência (MOREIRA, RIBEIRO E COSTA, 1992).

O sentimento da vítima para com o agressor passa a ser permeado pelo dualismo ante o envolvimento amoroso e a repulsa a agressão sofrida. Essa dualidade de sensações faz com que a mulher se cale mediante as agressões, pois passa a atribuir ao homem características que visam desculpabilizá-lo, tais como dificuldades emocionais, traumas, alcoolismo, consumo de drogas. Da mesma forma buscam aspectos positivos para acreditar que podem suportar as agressões a fim de preservar o relacionamento. Tal percepção é confirmada quando Margarida afirma que:

Ele era um homem direito, trabalhador, caráter de um homem assim de um bom casamento, mas porém era um homem muito orgulhoso e possessivo. (Relato de Margarida, dezembro de 2016). 
Dessa forma, observa-se que para ela, ser agredida por seu companheiro representa, em primeiro lugar, sentimento de desilusão com o relacionamento, o que causa desencanto com seu matrimônio e, especialmente, com a relação sexual do casal:

Falava: "não é possivel!" Pra mim casamento era uma coisa assim, saudável, né?! Era carinho, essas coisas, troca de carinho... ele mandava eu fazer coisas absurdas. Tanto é que eu passei a ter nojo do casamento, eu tinha sexo com ele e tudo, mas eu não tinha... [prazer] falava que tava bom, chamava ele de amor e tudo, mas na verdade, eu estava odiando, odiando... Então aí eu falava "Deus porque eu tenho que passar por isso tudo?" Eu não... Casamento pra mim não era isso, falei: "eu sempre sonhei em entrar na igreja de branco e tudo". Não entrei só casei no civil, sempre achei que casamento era alguém que cuidasse da gente. (Relato de Margarida, dezembro de 2016).

O sentimento de desencanto com o casamento, apresentado pela entrevistada, decorre do posicionamento subalterno da mulher nos espaços privados, e o desempenho de papéis sociais subservientes. Mesmo com as novas configurações da sociedade, que se deram com o passar do tempo, o patriarcado manteve suas premissas pautadas no poder e na autoridade masculinos e a mulher arcou com o ônus da restrição de sua atuação social. Nesse arranjo a vida familiar imposta pela sociedade continua a exigir um tipo de mulher dedicada ao cuidado dos filhos e com a organização da casa, da mesma forma em que sua sexualidade presta-se mais a atender aos desejos do homem do que aos seus, submetendo-se a uma relação conjugal oposta ao ideal esperado por ela.

Nesse sentido, a e entrevistada relata atos de sujeição ao ato sexual com seu companheiro, demonstrando que as estratégias para enfrentar a relação sexual indesejada:

Não era marido e mulher, não tinha desejo, não tinha nada. Às vezes eu até, desculpa falar, eu até imaginava Roberto [um amigo que ela tinha e que despertava ciúmes no marido e é citado recorrentemente na entrevista] na hora pra poder acabar rápido. Pedia a Deus pra acabar rápido, pedia a Deus pra acabar o sentimento de alegria dele e tudo porque eu tinha nojo, nojo! Então, foi um bom tempo vivendo de casamento assim de fachada. Chamava ele de amor, quando na verdade não queria chamar. (Relato de Margarida, dezembro de 2016). 
Insistir no relacionamento com episódios de violência, para a maioria das mulheres, ocorre por questões interpessoais e pela cobrança da sociedade para que tenham um companheiro de maneira permanente.

A convivência com um companheiro constantemente violento era a realidade da entrevistada, pois para o ex-marido de Margarida, todo dia era dia de colocar em prática suas investidas violentas. Ela nos diz que a violência era constante e demonstra seu posicionamento de subserviência com o companheiro e com as tarefas domésticas, socialmente atribuídas como obrigações da mulher:

Só que eu não sabia, então ele me batia assim, eu nem sabia por que ele estava me batendo. Aí, às vezes, eu sentia um vazio por dentro assim... [emoção]. Você não tem ânimo pra fazer nada, assim você faz a comida, você sabe que tem que dar comida pro seu esposo, tem que arrumar a casa pro seu esposo, isso, aquilo. Então, eu vivia uma vida assim, sem sentido mesmo, sem gosto. Fazia tudo por fazer. (Relato de Margarida, dezembro de 2016).

Percebe-se ainda que a entrevistada demonstra sua introjeção à naturalização do seu papel social de esposa e os cumprimentos às tarefas domésticas de cuidado com a casa. Os padrões culturais e históricos da sociedade interferem na determinação biológica na divisão dos papéis sociais, conferindo rigidez no dualismo dos padrões de ser homem e ser mulher.

É pela influência do patriarcado na cultura brasileira que são reforçados os discursos normativos que atribuem tais distintos papéis sociais para homens e mulheres e legitimam a dominação masculina, determinando ao homem a função de chefe da casa e à mulher, sua subalterna e dependente. Dessa maneira, o patriarcado enquanto sistema sócio-político subjuga as mulheres subordinando-as à realização de serviços domésticos aos membros da família (BRUSCHINI, 1990).

Nessa lógica o espaço doméstico foi sendo desvalorizado da mesma forma que todo o tipo de trabalho ou atuação nele. No âmbito privado a dominação masculina se faz presente e é reiterada pelo patriarcado enquanto sistema de exploração. A força da ordem masculina pode ser aferida pelo fato de que ela não precisa de justificação, como nos afirma Bourdieu (2005). A violência simbólica está de tal forma incorporada na relação de dominação que parece ser algo natural. É por meio dessa dominação 
simbólica que Margarida afirma que "você sabe que tem que dar comida pro seu esposo, tem que arrumar a casa pro seu esposo", pois a sociedade espera que a mulher faça tudo para agradar seu marido (NADER, 2006).

$\mathrm{Na}$ família, a hegemonia masculina se ancora no patriarcado como sistema de “dominação-exploração", como considera Saffioti (1987). Para a autora, a dupla dimensão do patriarcado está presente tanto quando a mulher desempenha o papel de dona de casa quanto no de trabalhadora. No primeiro ela é explorada pelo marido, nas atribuições domésticas, e no último, ao ser obrigada a aceitar menores salários é explorada pelo empresário capitalista.

O sistema de valores produzido pela sociedade e reproduzido nas relações familiares afirma a situação de dupla exploração da força de trabalho feminino e legitima a inserção da mulher na produção sem questionar a divisão sexual do trabalho doméstico.

A subordinação da mulher ao homem é marcante no campo econômico e mesmo que ela trabalhe fora de casa em troca de um salário, cabe-lhe realizar todas as tarefas domésticas (SAFFIOTI, 1987).

A família é o lugar do adestramento para a adequação social (Bruschini, 1990, p. 55) e nesse espaço os homens utilizam seu poder de dominação para ajustar condutas femininas que não sejam compatíveis com os códigos morais patriarcais nos quais foram adestrados e agem com violência para praticá-los.

No caso da entrevistada, o marido questionava o cumprimento de atividades domésticas exercendo o poder do macho $^{8}$, subordinando a esposa e exercendo a supremacia do macho adulto, garantida pelo patriarcado:

(...) Ele falava "ô mulher porque você não lavou isso aqui, por quê a cozinha tá assim?" Me tratava de forma brusca, como se fosse não mulher dele, mas sim como empregada. Tinha vergonha de eu eu sair com ele. Ttinha festa de amigos que ele ia não me levava. (Relato de Margarida, dezembro de 2016).

Para controlar ações diversas ao que é normatizado pela sociedade, os homens agem com violência, que, pautada no patriarcado, é um componente cultural de nossa sociedade e faz com que utilizem-na como forma de controle social sobre as

\footnotetext{
${ }^{8}$ Expressão utilizada por Heleieth Saffioti (1987), que afirma que dada sua formação de macho, o homem julga-se no direito de espancar sua mulher (p. 79).
} 
mulheres. Assim, o patriarcado legitima o poder dos homens de determinar a conduta das mulheres e por estar naturalizado nas relações sociais cria-se permissividade com relação a violência cometida contra as mulheres.

\section{O silenciamento por razões econômicas}

A dependência econômica por parte das mulheres representa uma das causas do silenciamento dos casos de violência conjugal. Margarida, na entrevista concedida para a pesquisa, relata esse aspecto:

Eu vivi no casamento... eu só tinha confiança, meu Deus do céu, eu tinha confiança nele! E pra mim eu dependia só dele porque ele não deixa eu trabalhar, não deixa eu fazer nada. Então tudo que eu tinha, na minha cabeça, eu dependia dele. Eu tenho que tratar ele bem, por causa da minha filha. Eu tenho que tratar bem dele porque ele que paga minha comida, ele que faz isso e aquilo. (Relato de Margarida, dezembro de 2016).

A dependência econômica do parceiro inviabiliza a separação e causa insegurança das mulheres na tomada de decisão sobre suas vidas. A pesquisa de Maria Beatriz Nader (2008) com as mulheres capixabas constatou que depois de deixarem de depender economicamente do pai e/ou do marido, as mulheres passam a se relacionar de forma diferente com o casamento. Ao assumirem novos papéis sociais, começam a considerar o trabalho como possibilidade de realização social, em detrimento do matrimônio, antes concebido como projeto ideal feminino.

Da mesma maneira, Amartya Sen (2000) destaca, dentre os fatores relacionados ao empoderamento da mulher estão: o nível de estudo, a possibilidade ser proprietária e as oportunidades de emprego. Segundo o autor, o alcance das "liberdades substantivas" estaria relacionado à qualidade de vida, à segurança econômica e física. Ademais, o direito de propriedade, as possibilidades de emprego fora de casa e de renda própria contribuiriam para fortalecer a condição de agente das mulheres.

Para Sen (2000) o empoderamento econômico da mulher seria processualmente construído e contaria com o suporte da obtenção de uma renda, seja 
por meio do trabalho individual, seja coletivo, auferido a partir do ganho advindo de um emprego fora de casa. Assim, Sen (2000) considera que a independência econômica é indispensável para o reconhecimento da condição de agente por parte dos indivíduos, por fazer com que eles se sintam como pessoas responsáveis por sua vida e emancipados.

A dependência financeira constitui traços de união muito mais fortes do que os laços de amor, de carinho e de solidariedade (SAFFIOTI, 1987). Isso porque o patriarcado abarca um sistema mais amplo do que a ideologia machista, pois consiste num sistema de exploração que está fundamentalmente ligado ao setor econômico.

Em vista disso, a conquista do espaço público por meio do trabalho remunerado representa uma possibilidade de romper as amarras de uma relação conjugal opressora e violenta e sustentar decisões e posicionamentos por parte das mulheres.

O empoderamento da mulher por meio do ingresso no mundo do trabalho pode ser considerado como um dos alicerces do processo de enfrentamento da violência.

\section{O silenciamento por razões sociais}

As regiões interioranas do país são as que mais carregam o legado patriarcal no comportamento de sua população, tendo em vista que a formação da sociedade brasileira teve sua base em locais onde a cultura do patriarcado se firma na figura do patriarca e no forte predomínio da ordem privada sobre a ordem pública.

Em pesquisa realizada em São João Nepomuceno, pequena cidade da Zona da Mata de Minas Gerais, Márcio Caniello (2003), apresenta a peculiaridade da sociabilidade nas pequenas cidades, a qual define como "largamente condicionada pela pessoalização”. Essa proximidade entre as pessoas produz o que o autor nomeia por "visibilidade inevitável". Destaca que nessas localidades a individualidade dissolve-se em uma rede de relacionamentos compulsórios ditados pela freqüência do contato no cotidiano.

Levando-se em conta a visibilidade latente entre os indivíduos que residem em localidades pequenas, há que se considerar que o fator da pessoalização influencie no silenciamento das mulheres com relação a violência doméstica na cidade de Carangola. 
Em uma cidade pequena como Carangola, além da proximidade com os vizinhos - que também é comum em localidades maiores - é comum que parentes residam próximos aos outros. Esse tipo de contato faz com que a violência seja vivenciada por todos, como no caso específico de Margarida, que tinha uma prima que era sua vizinha:

Aí pegou um garfo quente e enfiou assim no meu pescoço, nisso eu comecei a chorar e a minha prima em cima falou "Margarida, sobe agora aqui pra casa e traz os meninos" me enrolei na toalha e subi com meus menino.(Relato de Margarida, dezembro de 2016).

Tanto em cidades de pequeno porte, quanto nas grandes cidades, os vizinhos são aqueles que sempre testemunham agressões, mesmo que se calem temendo represálias. No relato de Margarida ela faz menção ao conhecimento dos vizinhos com a violência do marido:

Ai que eu fiquei sabendo que a minha prima e a vizinhança lá em cima sabiam que todo dia à noite eu era espancada por ele. E nisso levou lá pro meu tio de Fervedouro. Falava: "sua sobrinha vai acabar morta aqui, porque todo dia chega a noitinha ou madrugada ela..."(Relato de Margarida, dezembro de 2016).

No que se refere a sociabilidade, Norbert Elias (1990) em "A Sociedade de Corte" destaca que os modos de vida em sociedades onde há proximidade entre os indivíduos a arte de observar os outros e censurar sentimentos são como normas que disciplinam ações. Dessa maneira, numa cidade pequena, a comunidade confere vigilância às ações das famílias, o julgamento moral é constante e recriação narrativa dos fatos também. Mesmo que haja silenciamento da violência, por parte das mulheres, sempre haverá alguém que saiba que existe uma mulher vivenciando agressões aqui ou acolá. A comunidade sempre pensa a violência sofrida pela mulher é um problema de foro íntimo e vai buscar justificativas para tal fato.

\section{Denúncia e enfrentamento}


Ao vencerem a barreira do silêncio, as mulheres que denunciam a violência tornam-se sujeitos e buscam novas formas de realização pessoal, o fortalecimento de suas imagens, enfim, o recomeço de suas vidas.

Já se sabe que as mulheres silenciam inúmeras agressões, até conseguirem realizar a primeira denúncia. Quando o silêncio não é mais suportável, procuram ajuda. Com a entrevistada não foi diferente. Ela reafirma, no trecho a seguir, a desilusão com o casamento e atitudes depressivas:

Teve um dia que a agressão foi tão forte que eu olhei pra ele e falei: "Deus que me perdoe, eu nunca te traí, mas eu vou te trair com o primeiro homem que aparecer na minha frente e mais velho que você, mas não vai ser o Roberto". Nesse dia eu estava com tanta raiva que não tava...[emoção] não tinha gosto pra filho, não sentia amor, não sentia nada, só tava querendo morrer e tudo. E eu andava... andava na rua chorando, então ele já estava assim nossa ... eles falam que eu tinha a aparência de uma doente, estava magra, eu era seca pra caramba; mas eu não tinha mais aquele brilho no olhar, não. (Relato de Margarida, dezembro de 2016).

Percebe-se que o ciclo da violência traz para a mulher todo um cenário de descrença e destruição da auto-estima e, nesse relato, Margarida menciona a notoriedade de seu abatimento físico por parte da comunidade, dada em razão de um cotidiano de agressividade.

O processo de agressões que culmina com a denúncia insurge com o desgaste da vítima, ao longo de todo o continuum de violência. No caso da entrevistada, ela contou com o incentivo da irmã, quando vivenciou a situação-limite:

Aí até ele me bater ele colocou eu e meus filhos pro lado de fora e era de noite, no escuro.. Aí a gente ficou lá. Depois não sei se bateu um arrependimento e ele falou pra gente que podia entrar pra vocês dormir. No dia seguinte foi de novo, ele pegou minha menina, estava nervoso e bateu. Aí machucou, deixou nela roxo e ai eu falei: "gente eu não aguento"! Eu estava assim... meu organismo já estava doente. Aí eu explodi falei que não aguentava mais. A minha irmã ligou eu falei "Cristina" ela perguntou porque eu estava chorando, porque eu chorava, chorava o tempo todo, todo. Ai ela falou "o João te agrediu?" Ai a Cristina falou "pega as duas crianças e vai agora ao Conselho Tutelar. Sai dessa casa. Porque se você não fizer isso 
eu vou aí e te busco". Ela é minha irmã do Rio. Aí peguei os meus meninos, eu não me recordo a data agora não... [silêncio]. Fui no Conselho Tutelar e falei: "Vim fazer uma ocorrência, pedir socorro e tudo. Só que eu não acredito em vocês"! Ai a Juliana, do Conselho Tutelar, falou: "Pode confiar". E eu falei: "É mas eu tenho medo de sair daqui e ver a morte. Como eu vou ter certeza que vocês vão me proteger?" Aí nisso ela falava um monte de coisa, não entrava nada na minha cabeça só saia, só sei que eu fui falando lá e ela registrando as coisa e tudo e, a minha irmã do Rio veio. Depois eu só me lembro de ter tirado tudo de dentro de casa, já estar fora de casa com os meninos e tudo. Minha irmã tinha vindo pra cá, arrumado um cantinho pra gente ficar. Eu não levei nada, a gente começou do zero e eu falei que não queria ver ele nunca mais. Depois ele voltou viu que a gente não estava em casaMas ai ele ficou sabendo que estava na lei Maria da Penha e que tinha que manter cem... de distância de mim. Mas nisso mesmo com a lei Maria da Penha e tudo ele ficava me perturbando. (Relato de Margarida, dezembro de 2016).

O período após a denúncia é temeroso para as vítimas de violência, tendo em vista que passam a conviver com o medo de investidas ainda mais graves, e podendo até mesmo, culminar com o feminicídio?.

Margarida expõe que após denunciar o marido, sentiu medo, e, ao quando questionada se recebeu apoio ou ajuda de alguém depois que formalizou a denúncia, ela responde:

Não ajuda, sabe o por quê? Porque mesmo as pessoas sabendo que você é boa e tudo, depois chega à noite é você, seus filhos e o pai dos seus filhos, e aí você paga. "Ah é?! Você contou pro vizinho?" Depois você via a morte todo dia. Por isso que eu falo: "Eu sou protegida de Deus. Deus me salvava todas as noites e meus filhos, meus filhos também"'”. Então ele não era mais severo comigo porque lá no fundo eu acho que ele pensava um pouco nos meninos, então ele batia assim já na consciência e me deixava no limite. Então o quê que acontece, ele não era nem um pouco romântico nem nada, ele me tratava... é o que eu te falei como tinha em outra conversa, como uma qualquer. Puta, piranha, Deus que me perdoe! Tudo de ruim porque ele falava também. (Relato de Margarida, dezembro de 2016).

\footnotetext{
${ }^{9}$ Para Pasinato (2011) sempre que a morte de uma mulher apresenta-se como um ponto final de um continuum de terror, deve ser considerada como femicídio. Imbutido nesse conceito estão as ideias de que as mortes das mulheres estariam relacionadas ao não cumprimento de seus papéis sociais, conforme normatizada pela sociedade patriarcal e que, também, resultariam da discriminação baseada em gênero.
} 
A relação de proximidade entre vítima e agressor, no caso da violência conjugal, intimida a mulher, causa insegurança e medo. No entanto, o rompimento com a situação de violência representa para a mulher a assunção a sua condição de agente e no fortalecimento de sua auto-imagem, que consiste, em alguns casos, na busca por trabalho remunerado, descobrindo novas formas de realização pessoal. Foi o que aconteceu com a entrevistada, conforme relata:

A empresa onde... ah, meus patrões! Nossa, eles mudaram minha vida, primeiro voto de confiança. Ele sim conheceu minha vida todinha [o patrão], é outro príncipe na minha vida! Ele me deu voto de confiança e tudo, porque, eu não tinha emprego de carteira assinada, não tinha nada. Eu era ninguém, ninguém nesse mundo, né, orfanato... (Relato de Margarida, dezembro de 2016).

Margarida, na concepção de Moreira, Ribeiro e Costa (1992), de vítima calada e isolada, passou a ser reconhecida como pessoa inteira, assumindo sua condição de sujeito. As autoras afirmam que a aceitação de fazer parte de uma pesquisa, de dar depoimentos e rememorar uma situação violenta e dolorosa representa a reflexão da própria experiência e a afirmação da capacidade de enunciar sua própria vivência.

A opção pelo enfrentamento, independente do longo processo de agressões vivenciado denota o sentimento de libertação do jugo do seu ex-companheiro e com toda a história de violência que a acompanha desde criança. Atualmente, Margarida faz acompanhamento no CREAS, em conjunto com sua filha, que se tornou agressiva após ter morado um tempo com o pai. A revolta da jovem por ter vivido tantas agressões, e, ainda, ter testemunhado as violências sofridas por sua mãe, nutriu um sentimento de rejeição à figura materna.

Mesmo sem contar com uma Casa de Acolhimento na cidade, com a finalidade específica de atender casos de violências contra a mulher, o atendimento Psicossocial oferecido pelo município à entrevistada e sua família tem sido relevante para o enfrentamento cotidiano da violência conjugal, que deixou muitos ranços na vida de Margarida. 


\section{CONSIDERAÇÕES FINAIS}

As diversas formas de violência contra a mulher fazem parte do cotidiano velado de muitas famílias brasileiras. Ao longo dos anos, desde quando o espaço privado começou a ganhar espaço nas pesquisas e discussões acadêmicas, vêm-se pensando possibilidades de enfrentamento da violência doméstica.

Para além das questões econômicas e sociais, compreender como os aspectos histórico-culturais da sociedade influenciam no comportamento de mulheres e homens é fundamental para o alcance de equidades. Desconstruir a hierarquia dos papéis sociais não é tarefa fácil numa sociedade marcada por códigos normativos patriarcais.

No entanto, trazer à tona a realidade diária de mulheres comuns consiste em estratégia de enfrentamento, pois contribui para o fim da invisibilidade e banalização da violência, vivenciada dia-a-dia, tão silenciada e tacitamente aceita pela população.

Dar vozes a essas mulheres oportuniza demonstrá-las como podem ser agentes de suas próprias histórias. Nem sempre elas sabem disso. 


\section{REFERÊNCIAS}

BRASIL. Ministério do Desenvolvimento Social e Combate à Fome. Orientações Técnicas: Centro de Referência Especializado de Assistência Social (CREAS). Brasília, 2011. Disponível em

http://www.mds.gov.br/webarquivos/publicacao/assistencia_social/Cadernos/orientacoe s creas.pdf. Acesso em: 11 jul. 2016.

BOURDIEU, Pierre. A Dominação Masculina. Tradução de Maria Helena Kühner. Rio de Janeiro: Bertrand Brasil, 2005.

BRUSCHINI, Maria Cristina Aranha. Mulher, casa e família: cotidiano nas camadas médias paulistanas. São Paulo: Fundação Carlos Chagas. Vértice, Editora Revista dos Tribunais, 1990.

CANIELLO, Márcio. O ethos sanjoanense: tradição e mudança em uma "cidade pequena". Mana, Rio de Janeiro, v. 9, n. 1, p. 31-56, Apr. 2003 . Disponível em http://www.scielo.br/scielo.php?script $=$ sci arttext\&pid=S010493132003000100003\&lng=en\&nrm=iso Acesso em 22 Sept. 2016.

DELGADO, Lucilia de Almeida Neves. História Oral. Memória, tempo, identidades. Belo Horizonte: Autêntica, 2010.

ELIAS, NORBERT. A sociedade de corte: Investigação sobre a sociologia da realeza e da aristocracia de corte. Tradução: Pedro Süssekind. Rio de Janeiro: Jorge Zahar, 1990.

MOREIRA, Maria Ignez Costa; RIBEIRO, Sônia Fonseca; COSTA, Karine Ferreira. Violência contra a mulher na esfera conjugal: jogos de espelhos. In.: COSTA, Albertina de Oliveira e BRUSCHINI, Cristina (Orgs.). Entre a virtude e o pecado. Rio de Janeiro: Rosa dos Tempos, 1992. p. 169-189.

NADER, Maria Beatriz. Paradoxos do progresso: a dialética da relação mulher, casamento e trabalho. Vitória: Edufes, 2008.

. Violência sutil contra a mulher no ambiente doméstico: uma nova abordagem de um velho fenômeno. In.: SILVA, Gilvan Dutra da; NADER, Maria Beatriz; FRANCO, Sebastião Pimentel.(Orgs.). História, mulher e poder. Vitória: EDUFES; PPGHis, 2006. P. 235-251. 
NORA. P. Entre memória e história: a problemática dos lugares. Proj. História. São Paulo (10), dez, 1993.

PASSERINI, Luisa. Gênero ainda é uma categoria útil para a história oral? In.: A memória entre política e emoção. Tradução Ricardo Santhiago. São Paulo: Letra e Voz, 2011.

PASINATO, Wania. "Femicídios" e as mortes de mulheres no Brasil. Cad. Pagu, no.37, Campinas, July/Dec., 2011

PERROT, Michelle. Práticas da memória feminina. Revista Brasileira de História, São Paulo: v.9, n. 18, pp.09-18, ago.89/set.89.

. As mulheres ou os silêncios da história. Bauru: EDUSC; 2005.

POLLAK, Michael. Memória, esquecimento, silêncio. Estudos Históricos, Rio de Janeiro: CPDOC-FGV, v. 2, n. 3, p. 3-15, 1989.

. Memória e identidade social. Estudos Históricos, Rio de Janeiro:

CPDOC-FGV, v. 5, n. 10, p. 200-212, 1992.

SAFFIOTI, Heleieth I. B. Gênero, patriarcado, violência. 2. ed. São Paulo: Editora Fundação Perseu Abramo, 2015.

. O Poder do Macho. São Paulo: Moderna, 1987.

SEN, Amartya Kumar. A condição de agente das mulheres e a mudança social. In: SEN, Amartya Kumar. Desenvolvimento como liberdade. Tradução Laura Teixeira Motta. São Paulo, Companhia das Letras, 2000. p. 220-235.

WAISELFISZ, Julio Jacobo. Mapa da Violência 2015. Homicídio de Mulheres no Brasil. ONU Mulheres / Organização Pan-Americana da Saúde / Organização Mundial da Saúde / Secretaria Especial de Políticas para as Mulheres / Faculdade LatinoAmericana de Ciências Sociais. Brasília, 2015. Disponível em: < http://www.mapadaviolencia.org.br/pdf2015/MapaViolencia_2015_mulheres.pdf $>$ Acesso em 25 jul. 2016.

\section{ENTREVISTA:}

MARGARIDA. Entrevista III. [dez. 2016]. Entrevistadora: Érika Oliveira Amorim. Carangola, 2016. 1 arquivo .mp3 (19 min.) 